\title{
Effect of blanching time on physicochemical characteristics and sensory evaluation of Aster scaber
}

\author{
Seo-Woo Beom ${ }^{1}$, Gui-Hun Jiang ${ }^{2}$, Jong-Bang Eun ${ }^{2 *}$ \\ ${ }^{1}$ Department of Cosmetology, Cheongam College, Suncheon 540-743, Korea \\ ${ }^{2}$ Department of Food Science and Technology and Functional Food Research Center, Chonnam National University, \\ Gwangju 500-757, Korea
}

\section{데치기 시간에 따른 참취의 이화학적 및 관능적 특성의 변화}

\author{
범서우 ${ }^{1} \cdot$ 강귀훈 $^{2} \cdot$ 은종방 ${ }^{2 *}$ \\ ${ }^{1}$ 청암대학교 향장피부미용학과, ${ }^{2}$ 전남대학교 식품공학과, 기능성식품연구센터
}

\begin{abstract}
This study investigated the changes in the physicochemical characteristics and sensory evaluation of Aster scaber by blanching treatment time. Aster scaber was blanched with $100^{\circ} \mathrm{C}$ hot water for $1 \sim 5 \mathrm{~min}$. At $100^{\circ} \mathrm{C}$ blanching, the total polyphenol contents of the sample blanched for 1 5 min ranged from 7.57 to $6.45 \%$ while the sample blanched for $5 \mathrm{~min}$ showed a severe loss of phenolic compounds. The sample blanched at $100^{\circ} \mathrm{C}$ for $5 \mathrm{~min}$ had the lowest $L^{*}$ and $b^{*}$ values $(24.96$ and 16.14, respectively) and the highest a* value (-10.39) among all the samples. With regard to the texture profile, the sample blanched at $100^{\circ} \mathrm{C}$ for $5 \mathrm{~min}$ was the highest in texture. Significant reductions in the texture, color, and total phenol content were observed after blanching. In the sensory evaluation, the Aster scaber sample blanched with hot water at $100^{\circ} \mathrm{C}$ for 2 min showed the highest color, appearance, and flavor while the sample heated with boiling water for $3 \mathrm{~min}$ had the highest sensory score in terms of texture and overall acceptability. In conclusion, the 3 min blanching of Aster scaber yielded the best sensory quality.
\end{abstract}

Key words : Aster scaber, physicochemical characteristics, sensory evaluation, blanching time

\section{서 론}

참취는 국화과(Compositae)에 속하는 여러 해살이 풀로 서 나물 취라고도 칭하며 학명은 Aster scaber $\mathrm{T}_{\mathrm{HUNB}}$ 이다. 생약명은 동풍채근, 산백채, 백운초고서 뿌리를 약재로 쓰 며 진통, 해독의 효능을 가지고 있으며 혈액순환을 촉진시 키는 작용과 근골통증, 요통, 두통, 장염으로 인한 복통, 인후염 등의 치료에 예부터 효과가 있는 것으로 알려져 왔다, 한국의 자원식물(1)에는 어린잎을 식용하고 관창초 및 민간에서 전초를 해수, 이뇨, 보익, 방광염, 두통, 현기증

*Corresponding author. E-mail : jbeun@jnu.ac.kr Phone : 82-62-530-2145, Fax : 82-62-530-2149

Received 25 September 2014; Revised 12 November 2014; Accepted 21 November 2014.

Copyright (c) The Korean Society of Food Preservation. All rights reserved.
등에 약으로 쓰는 방향성 식물로서, 어린잎을 가열처리한 나물이나 생식으로 섭취하였으며, 가볍게 데쳐서 혹은 건 조한 후 수시로 나물의 원료로 사용하였다.

참취는 $\mathrm{Ca}$ 과 $\mathrm{Fe}$ 이 풍부하며 $\beta$-carotene이 $3.6 \mathrm{mg} \%$ 로서 다량 함유되어 있고(2), Nagao 등(3)은 참취 뿌리로부터 oleanolic acid glycoside로서 scaberoside B1 B9의 구조를 학인 하였으며, 또한 echinocystic acid의 glycoside도 규명되 었다(4). Ham 등 $(5,6)$ 은 in vitro방법으로 곰취, 참취 등이 돌연변이 유발 억제 및 DNA 손상 억제에 대한 효과를 연구 보고하였으며, in vivo 방법으로는 쥐의 종양 축소 효과가 있음을 보고하였다. Hwangbo 등(7)은 참취 뿌리 추출물이 항 돌연변이 효과를 보고한 바 있다. 약용성분으로는 옹근 풀에 flavonoid, saponin 등이 있고, 꽃 이삭과 줄기에 정유가 있으며 뿌리에는 coumarin, saponin, alkaloid가 있다(8).

최근 단체급식소 및 외식업체 등을 중심으로 인력절감, 이용의 편리성, 조리시간 절감 등의 이점이 있는 전처리 
식재료의 사용이 증가하고 있다(9). 전처리 식재료의 수요 증가와 함께 식재료 시장의 규모는 최근 수년간 급속히 성장하였고, 향후 외식산업의 성장과 함께 그 수요가 지속 적으로 확대될 것으로 예측하고 있다 $(10,11)$. 이미 전처리 공정을 거친 채소나 과일을 구입하고자 하는 경향이 급증하 고 있으며, 단체급식의 경우 감자, 양파, 마늘 등 전처리 채소류, 나물류, 신선편이 채소류의 사용량은 이미 전체 채소류 사용량의 $80 \%$ 를 넘는 것으로 추정하고 있다 $(12,13)$. 채소, 과일, 버섯류에서 데치기 처리는 생산 및 유통기술 의 개선과 고품질 제품에 대한 소비자의 선호 추세에 따라 생식 또는 데치기 처리된 상태의 유통비율이 증가하고 있으 며, 특히 외식산업의 발전과 더불어 다양한 식품 원료로서 사용이 증가하고 있다. 그러나 데치기 처리는 제품을 연화 시키거나, 데치기 공정 중 색, 질감, 맛 및 향의 변화, vitamin $\mathrm{C}$ 등 수용성 영양성이에 vitamin $\mathrm{C}$ 등 수용성 영양성분의 괴 지용성 carotenoid의 산화 등의 문제와 같은 제품의 손실을 발생시킨다(14). 이에 대한 연구로서. Lisiewska 와 Kmiecik(15)은 동결 파슬리의 품질이 blanching에 의해서 더욱 향상되었다고 보고하였다. 또한, 감자에 대한 blanching 조건의 설정을 직접적으로 수행하고 $(16,17)$, peroxidase의 불활성에 대한 kinetics의 연구(18), blanching 을 위한 수학적 모델의 설정(19)과 영양적 가치의 저하에 대한 blanching의 영향(20)에 관해서 수행되어 왔으며, 국내 에서는 시금치(21) 및 콩나물(22)에 대한 영양성분의 변화 및 관능적 특성에 대한 연구가 주를 이루고 있으나, 취나물 에 대한 blanching 조건 및 이에 따른 이화학적 특성에 대한 연구가 미진하므로 이에 대한 체계적인 연구가 필요하다고 판단된다. 그러므로 고품질의 취나물의 제조를 위해서는 데치기 중 발생하는 품질변화에 대한 안정적인 유지기술이 필요하다.

따라서 본 연구에서는 즉석 편이 취나물 가공제품을 제조를 위한 참취의 적정 전처리 조건을 탐색하고자 데치기 시간에 따른 데쳐진 참취의 이화학적 및 관능적 특성을 조사하였다.

\section{재료 및 방법}

\section{실험재료}

본 실험에서 사용된 참취는 전라남도 구례군 토지면의 농가에서 5 월에 수확한 취를 구입하여 사용하였고 실험을 실시하는 동안 $4{ }^{\circ} \mathrm{C}$ 냉장고에 보관하면서 시료로 사용하였 다.

\section{참취 제조를 위한 전처리 조건}

시료의 전처리 조건은 예비 실험을 통하여 설정하였다. 참취를 흐르는 물에 3 번 수세한 후 체를 이용하여 물기를
제거하였고 끓는 물에서 $1,2,3,4,5$ 분 동안 데치기를 실시 하였다. 시료의 20 배 $(100 \mathrm{~L})$ 물을 특별히 제작된 항온수조 에서 가열하여 물이 끌을 때 시료 $5 \mathrm{~kg}$ 을 투입하여 각각 데치기 시간동안 데친 후 즉시 냉수에 냉각한 다음 증류수 로 1 화 헹구고 5 분 동안 체에 밭친 후 티슈로 남은 물기를 제거한 후 시료로 사용하였다.

색 도

색도는 spectrophotometer(CM-3500, MINOLTA, JAPAN) 을 이용하여 잎의 일정한 상당 부위를 10 번 이상 반복하여 측정하였다(24). 측정 전 표준백판( $\mathrm{L}=97.75, \mathrm{a}=0.49$, $\mathrm{b}=1.96)$ 으로 보정한 후 사용하였으며 $\mathrm{L}^{*}$ (명도, Lightness), $\mathrm{a}^{*}$ (적색도, redness), $\mathrm{b}^{*}$ (황색도, yellowness) 값으로 나타내 었다.

조직감

TA-XT2 texture meter(TA-XT2, Stable Micro Systems, England)를 이용하여 측정하였다. 데치기 처리한 참취 줄기 의 중앙 부분을 길이 $2 \mathrm{~cm}$ 정도 절단하여 그 부분을 $5 \mathrm{~mm}$ diameter probe으로 $0.1 \mathrm{~mm} / \mathrm{sec}$ 의 속도로 측정하였다(25). 참취의 최대 강도를 $\mathrm{kg} / \mathrm{cm}^{2}$ 단위로 나타내며 총 5 번 반복한 결과의 평균값으로 사용하였다.

\section{총 폴리페놀 함량}

참취의 폴리페놀 함량은 Folin-Denis법(23)으로 측정하 였다. 데친 시료 $0.2 \mathrm{~mL}$ 에 증류수 $1.8 \mathrm{~mL}$ 와 Folin- Ciocalteu's phenol reagent $0.2 \mathrm{~mL}$ 를 첨가한 후, vortex하여 3 분간 실온 에서 방치하였다. 여기에 $\mathrm{Na}_{2} \mathrm{CO}_{3}$ 포화용액 $0.4 \mathrm{~mL}$ 를 가하 여 혼합하고 증류수를 $1.4 \mathrm{~mL}$ 가하여 실온에서 1 시간동안 반응시킨 후 spectrophotometer를 사용하여 $725 \mathrm{~nm}$ 에서 흡 광도를 측정하였다. 총 폴리페놀 화합물의 정량은 tannic $\operatorname{acid(Sigma,~USA)ㄹㅡㄹ~ㅇㅣㅇㅛㅇㅎㅏㅇㅕ~ㅊㅚㅈㅗㅇㄴㅗㅇㄷㅗㄱㅏ~} 0,25,50,100$, $250,500 \mu \mathrm{g} / \mathrm{mL}$ 가 되도록 취하여 위와 동일한 방법으로 흡광도를 측정한 표준곡선으로부터 취의 폴리페놀 화합물 을 산출 하였다.

관능검사

데치기 한 후 참취의 색, 향, 외관, 전체적 기호도를 조사 하여 적절한 데치기 시간을 결정하였다. 이는 실험에 대한 관심도와 검사원으로 적합성이 인정된 식품공학과 학생 10 명의 관능검사요원을 선발하여 각각의 조건에 따라 데치 기와 수침을 한 참취의 관능적 특성을 7점 평점법(1점 : 매우 좋지 않음 7점 : 매우 좋음)을 사용하여 관능검사를 실시하였다(26).

\section{통계처리}

본 실험은 동일한 조건의 시료를 각각 2 개씩 취하여 분석 
하고자 하는 특성을 3 회씩 반복하여 분석하였고, 전체적인 실험을 2회 반복 실시하여 SAS program의 ANOVA 분석을 이용해 분산분석을 실시하여 유의차가 인정되는 항목을 Duncan's multiple range test로 5\% 수준에서 각 처리구별로 유의성을 검정하였다(27).

\section{결과 및 고찰}

색 도

식품에 있어서 색은 맛, 향 및 영양성분과 함께 그 식품의 가치를 나타내는 중요한 품질특성이다. Table 1은 참취를 $1,2,3,4,5$ 분 동안 끓는 물에서 데치기 한 색도를 측정한 결과이다. 명도를 나타내는 $\mathrm{L}^{*}$ 값은 $1,2,4$ 분에서 30.13 , $27.20,27.67$ 높은 값을 나타냈고, 데쳐진 시간이 증가함에 따라 감소하는 경향을 나타냈다. 적색 및 녹색을 나타내는 $\mathrm{a}^{*}$ 값은 꼻는 물에서 3 분 동안 데치기한 것이 가장 높게 나타 나 $(\mathrm{p}<0.05), \mathrm{L}^{*}$ 값과 반대되는 경향을 나타내었다. 이와 같이 적색도가 증가하는 것은 데치기 처리 시 높은 온도에서 아미노산의 peptide, 단백질의 a-amino group과 당과의 반응 에 의한 갈변 반응에 의한 것(28)으로 생각된다. 황색도 $\mathrm{b}^{*}$ 값 경우 16.14 24.84 범위로 처리구간에 유의적인 차이가 나타났으나 $(\mathrm{p}<0.05)$ 뚜렷한 경향은 나타나지 않았다. 따라 서 참취의 데치기 온도와 처리시간에 따라 $\mathrm{L}^{*}$ 값과 $\mathrm{a}^{*}$ 값에 영향을 미친다는 것을 확인할 수 있었다.

Table 1. Changes of Aster scaber treated for different times

\begin{tabular}{cccc}
\hline \multirow{2}{*}{$\begin{array}{c}\text { Blanching times } \\
(\min )\end{array}$} & \multicolumn{3}{c}{ Color value } \\
\cline { 2 - 4 } & $\mathrm{L}^{*}$ & $\mathrm{a}^{*}$ & $\mathrm{~b}^{*}$ \\
\hline 1 & $30.01 \pm 1.13^{\mathrm{b} 1)}$ & $-13.37 \pm 0.14^{\mathrm{a}}$ & $19.86 \pm 1.06^{\mathrm{ab}}$ \\
2 & $27.20 \pm 1.22^{\mathrm{b}}$ & $-13.73 \pm 0.67^{\mathrm{a}}$ & $23.35 \pm 3.16^{\mathrm{ab}}$ \\
3 & $23.38 \pm 0.37^{\mathrm{a}}$ & $-10.69 \pm 0.98^{\mathrm{b}}$ & $16.14 \pm 2.17^{\mathrm{a}}$ \\
4 & $27.67 \pm 2.43^{\mathrm{b}}$ & $-13.30 \pm 2.27^{\mathrm{a}}$ & $21.65 \pm 5.36^{\mathrm{ab}}$ \\
5 & $24.96 \pm 2.44^{\mathrm{a}}$ & $-10.39 \pm 1.51^{\mathrm{b}}$ & $24.84 \pm 5.36^{\mathrm{b}}$ \\
\hline
\end{tabular}

${ }^{1)}$ Values represent means \pm standard deviation, means followed by different letters in each column are significantly different $(\mathrm{p}<0.05)$.

\section{조직감}

조직감에서 경도는 제품 질감의 적합성을 보장하기 위해 필수적이며 품질의 가장 중요한 제약 조건중의 하나이다.

Fig 1은 꼻는 물에서 데치기 시간에 따른 참취의 경도를 측정한 결과이다. 참취를 데치기 처리 시 2 분과 3 분에서 $3.325 \mathrm{~kg} / \mathrm{cm}^{2}$ 로 높은 경도를 나타냈고, 5 분 동안 데치기 처리한 실험구가 가장 낮은 값 $2.425 \mathrm{~kg} / \mathrm{cm}^{2}$ 를 나타냈다. 이는 데치기 시간이 길어질수록 취나물의 경도가 감소하므 로 데치기 처리에 의해 참취 조직의 연화가 진행되는 것을 확인할 수 있었다. 이러한 결과는 Jung 등(29) 데치기 조건
과 가열 조건에 따른 참취의 품질 특성 변화 연구와 비교하 여 볼 때 본 실험과 유사한 경향을 나타냈다. 이는 열을 처리하는 동안, 가공 된 과일과 야채의 질감을 변경은 효소 및 화학 반응의 범위에서 발생할 것으로 사료된다.

\section{총 폴리페놀 함량}

페놀성 화합물들은 식물계에 존재하는 2 차 대사산물의 하나이며 분자 내에 phenolic hydroxyl 기를 가지고 있는 방향족 화합물로 단백질과 같은 거대 분자와의 결합을 통해 여러 가지 생리기능을 지닌다. 데친 참취의 총 폴리페놀 함량은 Table 2 와 같다. 데쳐진 참취의 총 폴리페놀 함량은 $0 \sim 5$ 분까지 $6.45 \sim 8.53 \mathrm{mg} / \mathrm{g}$ 범위를 나타냈고, 데치기 시간이 0-4분까지는 참취의 총 폴리페놀 함량이 큰 차이가 없다가 데치기 5 분 후에는 $6.45 \%$ 나타냈으며 약간 감소하였다. 이러한 결과는 Choi 등(30)은 데치는 시간이 증가함에 따라 취의 총 폴리페놀의 함량이 유의적으로 감소하였고 Lutz 등 (31)은 일반적으로 요리나 끓는 물에 야채를 데칠 때 산화로 인해 열을 분해하여 영양 특성 및 항산화제의 손실 이 감소 및 화합물이 침출하여 총 폴리페놀 함량이 감소하 였다고 보고하였다. 또한 Jung 등(30)에 의하면 총 phenol 함량은 신선한 참취에 비하여 데치기 조건에 의하여 49.5 $54.4 \%$ 의 감소를 나타내었다고 하였다. 따라서 본 연구에서 는 5 분 이후로 데치기 시간이 증가할수록 총 폴리페놀 함량 이 감소하므로 데치기 시간을 5 분 이내로 하는 것이 참취의 영양성분을 유지시킬 수 있다고 생각된다.

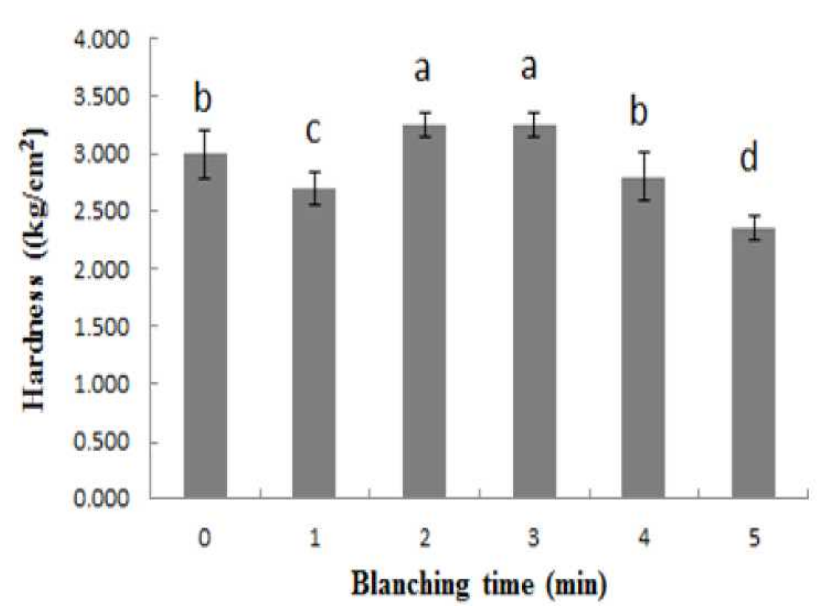

Fig. 1. Hardness of Aster scaber treated for different times.

관능평가

참취를 데친 직후의 데치기 조건에 따른 관능적인 특성 을 7점 척도법으로 조사하였으며 결과를 Table 3에 나타내 었다. 데치기 처리한 참취의 색, 향, 외관에서는 2 분과 3 분 데치기를 실시한 실험구에서 4 분, 5 분 데치기를 한 실험구 보다 유의적으로 높은 값을 보였고, 데치기 시간 5분 후 색과 외관에서는 3.67 과 4.22 로써 가장 낮은 값을 나타냈는 
Table 2. Total polyphenol content of Aster scaber treated for different times

\begin{tabular}{ccccccc}
\hline Blanching times $(\mathrm{min})$ & 0 & 1 & 2 & 3 & 4 & 5 \\
\hline Total phenol content $(\mathrm{mg} / \mathrm{g})$ & $7.57 \pm 0.28^{\mathrm{b} 1)}$ & $7.85 \pm 0.23^{\mathrm{bc}}$ & $7.59 \pm 0.33^{\mathrm{b}}$ & $7.92 \pm 0.06^{\mathrm{bc}}$ & $8.53 \pm 0.71^{\mathrm{c}}$ & $6.45 \pm 0.59^{\mathrm{a}}$ \\
\hline
\end{tabular}

${ }^{1)}$ Values represent means \pm standard deviation, means followed by different letters in each column are significantly different $(\mathrm{p}<0.05)$.

Table 3. Sensory evaluation of Aster scaber treated for different times

\begin{tabular}{cccccc}
\hline Blanching times (min) & Color & Flavor & Appearance & Texture & Overall acceptability \\
\hline 1 & $4.11 \pm 0.78^{\mathrm{ab} 1)}$ & $4.22 \pm 1.30^{\mathrm{NS}}$ & $4.89 \pm 0.93^{\mathrm{ab}}$ & $5.00 \pm 1.12^{\mathrm{ab}}$ & $4.67 \pm 0.87^{\mathrm{ab}}$ \\
2 & $5.56 \pm 0.88^{\mathrm{b}}$ & $5.11 \pm 0.78$ & $5.33 \pm 0.71^{\mathrm{b}}$ & $5.00 \pm 0.57^{\mathrm{ab}}$ & $5.00 \pm 0.71^{\mathrm{bc}}$ \\
3 & $5.22 \pm 0.97^{\mathrm{bc}}$ & $5.22 \pm 1.20$ & $5.11 \pm 0.78^{\mathrm{ab}}$ & $5.33 \pm 0.71^{\mathrm{b}}$ & $5.78 \pm 0.83^{\mathrm{b}}$ \\
4 & $4.89 \pm 1.62^{\mathrm{bc}}$ & $4.56 \pm 1.42$ & $4.56 \pm 1.42^{\mathrm{ab}}$ & $5.33 \pm 1.00^{\mathrm{b}}$ & $5.56 \pm 1.13^{\mathrm{bc}}$ \\
5 & $3.67 \pm 1.23^{\mathrm{a}}$ & $4.56 \pm 1.59$ & $4.22 \pm 1.20^{\mathrm{a}}$ & $4.22 \pm 0.67^{\mathrm{a}}$ & $4.00 \pm 1.32^{\mathrm{a}}$ \\
\hline
\end{tabular}

${ }^{1)}$ Values represent means \pm standard deviation, means followed by different letters in each column are significantly different $(\mathrm{p}<0.05)$.

데 이는 데치기 처리에 의해 시간이 지날수록 초록색의 손실이 감소하는 것으로 사료 된다. 끓는 물에서 데치기 3 분 처리한 실험구가 다른 실험구에 비하여 경도가 높은 점수로 평가되었고 데치기 시간이 길어질수록 낮은 값을 나타내었다. 이는 열에 의해 참취 조직의 손상으로 인하여 조직 강도가 떨어져 경도가 낮게 나타난 것으로 판단되었 고, 본 연구에서의 경도 측정 결과와 유사하였다. 전체적인 기호도는 이러한 조직감에 영향을 많이 받는 것으로 보여, 색, 향 및 외관에서 2 분 과 3 분 데치기한 실험구가 유사한 결과를 나타냈지만 조직감에서는 3 분 데치기한 실험구가 2분 데치기한 실험구보다 유의적으로 높은 값을 나타내어 전반적인 기호도에서 더 우수한 결과를 나타내었다.

\section{요 약}

본 연구에서는 데치기 시간에 따른 참취의 이화학적 및 관능적 특성을 조사 하였다. 색도 $\mathrm{L}^{*}$ 값에서는 3 분 데치기 한 실험구를 제외한 다른 실험구가 유의적으로 높은 값을 보였으며 $\mathrm{a}^{*}$ 값에서는 3 분, 5 분, 데치기한 실험구에서 높은 값을 보였으며, $\mathrm{b}^{*}$ 값에서는 5 분 데치기 처리한 실험구가 3 분 데치기한 실험구보다 높은 값을 보였으나 다른 실험구 와 유의적인 차이가 없었다. 조직감에서 경도는 참취를 데 치기 처리 2,3 분 한 실험구에서 다른 실험구보다 유의적으 로 높은 값을 나타내었으며 총 폴리페놀 함량은 데치기 1 분부터 4 분까지는 유의적으로 큰 차이가 없다가 5 분 후에 는 낮은 함량을 보였다. 관능평가에서는 참취의 색, 향, 외관 에서는 2 분 데치기 처리한 실험구에서 유의적으로 높은 값을 보였으나, 조직감, 전체적인 기호도에서는 3 분 데치기 처리한 실험구에서 유의적으로 높은 값을 보였다.

\section{감사의 글}

본 연구는 2008년 5월부터 2009년 5월까지 농림수산식 품부 농림기술관리센터의 지원 사업비로 이루어진 결과이 며, 이에 감사드립니다.

\section{References}

1. Kim TJ (1996) Korean resources plants. IV. Seoul Univ., p 230

2. Food composition table (1996) Rural living science institute, RDA, Sowon, Korea, p 126

3. Nagao T, Okabe H (1992) Studies on the constituents of Aster scaber Thumb. III. Structures of scaberosides $\mathrm{B} 7, \mathrm{~B} 8$, and $\mathrm{B} 9$, minor oleanolic acid glycosides isolated from the root. Chem Pharm Bull, 40, 886-888

4. Nagao T, Tanaka R,. Iwase Y, Okabe H (1993) Studies on the constituents of Aster scaber Thumb. IV. Structures of four new echinocystic acid glycosides isolated from the herb. Chem Pharm Bull (Tokyo), 41, 659-665

5. Ham SS, Lee SY, Oh DH, Jung SW, Kim SH Chung CK, Kang IJ (1998) Antimutagenic and antigenotoxic effects of Ligularia fischeri extracts. J Korean Soc Food Sci Nutr, 27, 745-750

6. Ham SS, Han SH, Choi KP, Oh DH (1997) Inhibitory effects of Synurus deltoides extracts on the mutagenesis induces by various mutagens. J Korean Soc Food Sci Nutr, 26, 528-533

7. Hwangbo HS, Ham SS (1999) Antimutagenic and cytotoxic effects of Aster scaber root ethanol extract, 
Korean J Food Sci Techol, 31, 1065-1070

8. Illustrated book for emergency plants (1997) National Honam agricultural experiment station. RDA, p 221

9. Jin HB, Choi CO (2001) Survey on the use of preprocessed foods in elementary school food services in Incheon. Korean J Food Cult, 16, 250-259

10. Jin HB, Choi EO (2000) Preception on using preprocessed foods among dietitians employed in elementary school food service in Incheon. Korean J Die Cult, 15, 379-386

11. Han JS, Lee SY, Seo KM (2002) The evaluation of quality management standards for contracted foodservice company. Korean J Soc Food Cookery Sci, 18, 426-432

12. Um HJ, Kim DM, Choi KH, Kim GH (2005) A survey on consumer's perception of fresh-cut agri-food products for quality enhancement. J Korean Soc Food Sci Nutr, 34, 1566-1571

13. Lee SJ, Lee SM (2006) Survey on the use of pre-processed food materials in school food services in the Kyunggi area. Korean J Food Cookery Sci, 23, 553-564

14. Ryley J, Kajda P (1994) Vitamins in thermal processing. Food Chem, 49, 119-129

15. Lisiewska Z, Kmiecik W (1997) Effect of freezing and storage on quality factors in hamburg and leafy parsley. Food Chem, 60, 633-637

16. Arroqui C, Rumsey TR, Lopez A, Virseda P (2001) Effect of different soluble solids in the water on the ascorbic acid losses during water blanching of potato tissue. J Food Eng, 47, 123-126

17. Arroqui C, Rumsey TR, Lopez A, Virseda P (2002) Losses by diffusion of ascorbic acid during recycled water blanching of potato tissue. J Food Eng, 52, 25-30

18. Mukherjee S, Chattopadhyay PK (2007) Whirling bed blanching of potato cubes and its effects on product quality. J Food Eng, 78, 52-60

19. Tijskens LMN, Barringer SA, Biekman ESA (2001) Modelling the effect of $\mathrm{pH}$ on the colour degradation of blanched broccoli. Inno Food Sci Emerg Technol, 315-322

20. Amin I, Norazaidah Y, Hainida KIE (2006) Antioxidant activity and phenolic content of raw and blanched Amaranthus species. Food Chem, 94, 47-52

21. Jang JD, Kim GT, Lee DS (2004) Effect of package size and pasteurization temperature on the quality of sous vide processed spinach. Korean J Food Preserv, 11, 195-200

22. Lyu ES, Lee DS (2004) Vitamin retention and acceptance evaluation of cook-chill and sous-vide soybean sprouts products. J Korean Soc Food Sci Nutr, 730-735

23. Swain T, Hillis WE, Ortega M (1959) Phenolic constituents of Ptunus domestica. I. Quantitative analysis of phenolic constituents. J Sci Food Agric, 10, 83-88

24. Min JS, Lee M (1999) Changes in physicochemical characteristics during the storage of the chilled pork loins treated with electron-beam irradiation. Korean J Anim Sci, 41, 45-50

25. Yook HS, Lee KH, Lee JW, Kang KO, Byun MW (1998) Effect of gamma-irradiation on lipid oxidation of Korean beef. Korean J Food Sci Technol, 30, 1179-1183

26. Choi HS, Yeo KM (1998) Foods quality assurance. Shim Gwang Press Seoul, Korea, p 141

27. Park GB, Kang SH, Kim YJ, Lee HG, Kim YH (1988) Changes in meat protein of Korean native goats meat during postmortem storage. Korean J Anim Sci, 30, 123-129

28. Jeon MR, Kim MH, Kim MY, Kim MR (2009) The effects of heat treatments and herb addition on flavor of garlic. J Korean Soc Food Sci Nutr, 38, 105-110

29. Jung JY, Lim JH, Jeong EH, Kim BS (2007) Effects of blanching conditions and salt concentrations on the quality properties of Aster scaber. Korean J Food Preserv, 14, 584-590

30. Choi NS, Oh SS, Lee SM (2001) Changes of biological functional compounds and quality properties of chamchwi by blanching conditions. Korean J Food Sci Technol, 33, 745-752

31. Lutz M, Henríquez C, Escobar M (2011) Chemical composition and antioxidant properties of mature and baby artichokes (Cynara scolymus L.), raw and cooked. J Food Comp Anal, 24, 49-54 